\title{
FAST ASSEMBLY OF QUALITY SUSPENDED VENTILATED FACADES
}

\author{
Yuriy Kazakov ${ }^{1}$, Aleksandr Birjukov²
}

\author{
${ }^{1}$ Saint Petersburg State University of Architecture and Civil Engineering \\ Vtoraja Krasnoarmejskaja ul. 4, St. Petersburg, Russia \\ ${ }^{2}$ Military (engineering) Institute of the Military Academy of Logistics and Transport n.a. army general A.V. Khrulyov, \\ Zakharevskaia ul. 22, Saint Petersburg, 190000, Russia \\ ${ }^{1}$ kazakov@spbgasu.ru, ${ }^{2}$ aleks_bir@mail.ru
}

\begin{abstract}
Previously understudied new structural and technological concepts of various types of modern suspended ventilated facades (SVF) applicable in Russia by 2017 were researched by a system and analysis method to determine their advantages and disadvantages. Theoretical bases and the algorithm for the development of the optimal technological solution for the installation of SVF were worked out with the aid of the methods of multi-criteria optimization. The structure and the operating sequence were substantiated for the rational technology of integrated mechanized process of SVF elements installation. Alternate improved technological solutions were developed for installation of heat insulating, framing and facing SVF elements with the account of the most important optimality criteria. These criteria include minimum labor intensity and machine time, minimum cost, enhanced quality and safety.

Effects of the most important factors related to labor intensity and cost improvement of construction operations as well as increase of SVF useful life under various building conditions were defined and substantiated by experimental construction of residential buildings with SVF facing.

With the aid of the methods of alternate technological design and multi-criteria optimization, 4 optimized variants of technological solutions for installation of thermal insulation, frame and facing elements in SVF systems were developed with the account of the 4 most important consumer optimality criteria: minimum labor intensity and machine time, minimum cost, enhanced quality, maximum quality and safety. The scientific significance of the results is that the major factors affecting optimization of technological modes of various SVF designs were identified and studied. Their use allows reducing the labor intensity of works to $0.55-1.79$ man-shift per 1 sq. $\mathrm{m}$ of facade area.
\end{abstract}

\section{Keywords}

Front elevation, assembling, labour inputs, optimization, ventilation.

\section{Introduction}

At the Saint Petersburg State University of Architecture and Civil Engineering the authors in cooperation with A.Ye. Piskun, and on the basis of his work, performed a further theoretical justification of the rational technological solution development for SVF design. The work objective is scientific substantiation and development of improved variants for design of suspended ventilated facades optimized in terms of the following criteria: minimum labor intensity and machine time, minimum cost, improved quality and safety during construction of residential buildings. The object of study is construction process and struc- tural-and-technological solutions for design of improved rational variants of suspended ventilated facades for the purposes of erection of various types of residential buildings in Russia.

\section{Methods}

Comparative variant technological design, technical-and-economic system analysis of engineering solutions, full-scale experiments with SVF fragments, theoretical modeling, test measuring and studying technological parameters of walling processes for residential buildings, 
mathematical statistics and the probability theory while solving optimization problems.

Dependencies (new and important for reducing labor intensity and cost as well as for enhancing simplicity and technological effectiveness of works) of increase in labor intensity on increase in area of mounted SVF elements, their weight and other impact factors were defined with optimality criteria of minimum cost, labor intensity and maximum quality. With use of mathematical statistics methods mathematical models that approximate the discovered dependencies were calculated. With the aid of the on-site measurement method new important dependencies of decrease in labor intensity during SVF design on the impact of the most important natural climatic factors - extremely low temperatures and wind velocity - were determined. High technical and economic efficiency and constructability were proved for the application of improved and efficient SVF solutions, intended for residential buildings in

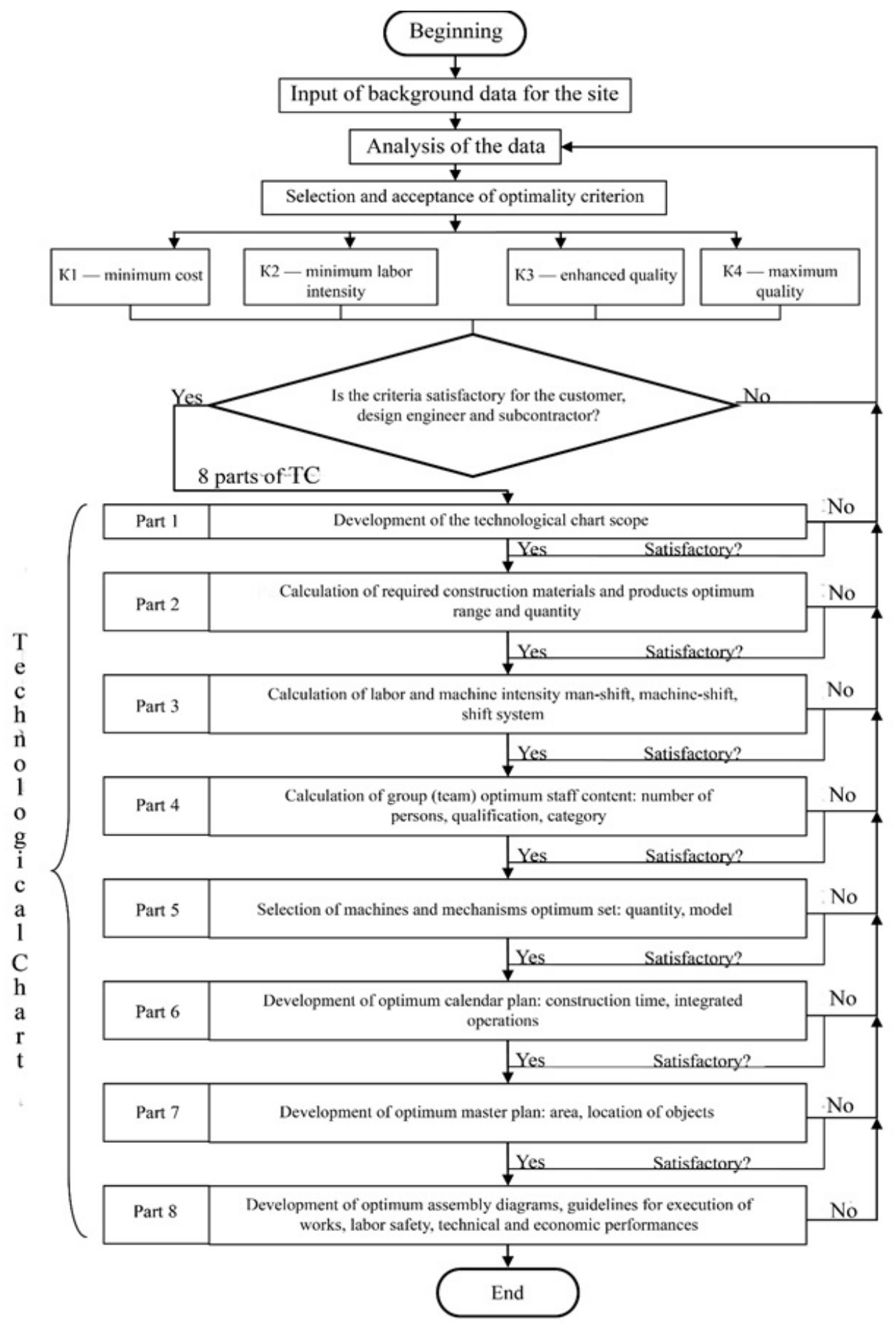

Figure 1. Theoretical bases for the development of optimal technological solution for installation of SVF with the aid of the method of step-by-step multi-criteria optimization 
terms of labor intensity and cost of work, effective useful life of heat insulating structures and their repairability.

With the aid of the methods of alternate technological design and multi-criteria optimization, 4 optimized variants of technological solutions for installation of thermal insulation, frame and facing elements in SVF systems were developed with the account of the 4 most important consumer optimality criteria: minimum labor intensity and machine time, minimum cost, enhanced quality, maximum quality and safety. The scientific significance of the results is that the major factors affecting optimization of technological modes of various SVF designs were identified and studied. Their use allows reducing the labor intensity of works to $0.55-1.79$ man-shift per $1 \mathrm{sq}$. $\mathrm{m}$ of facade area.

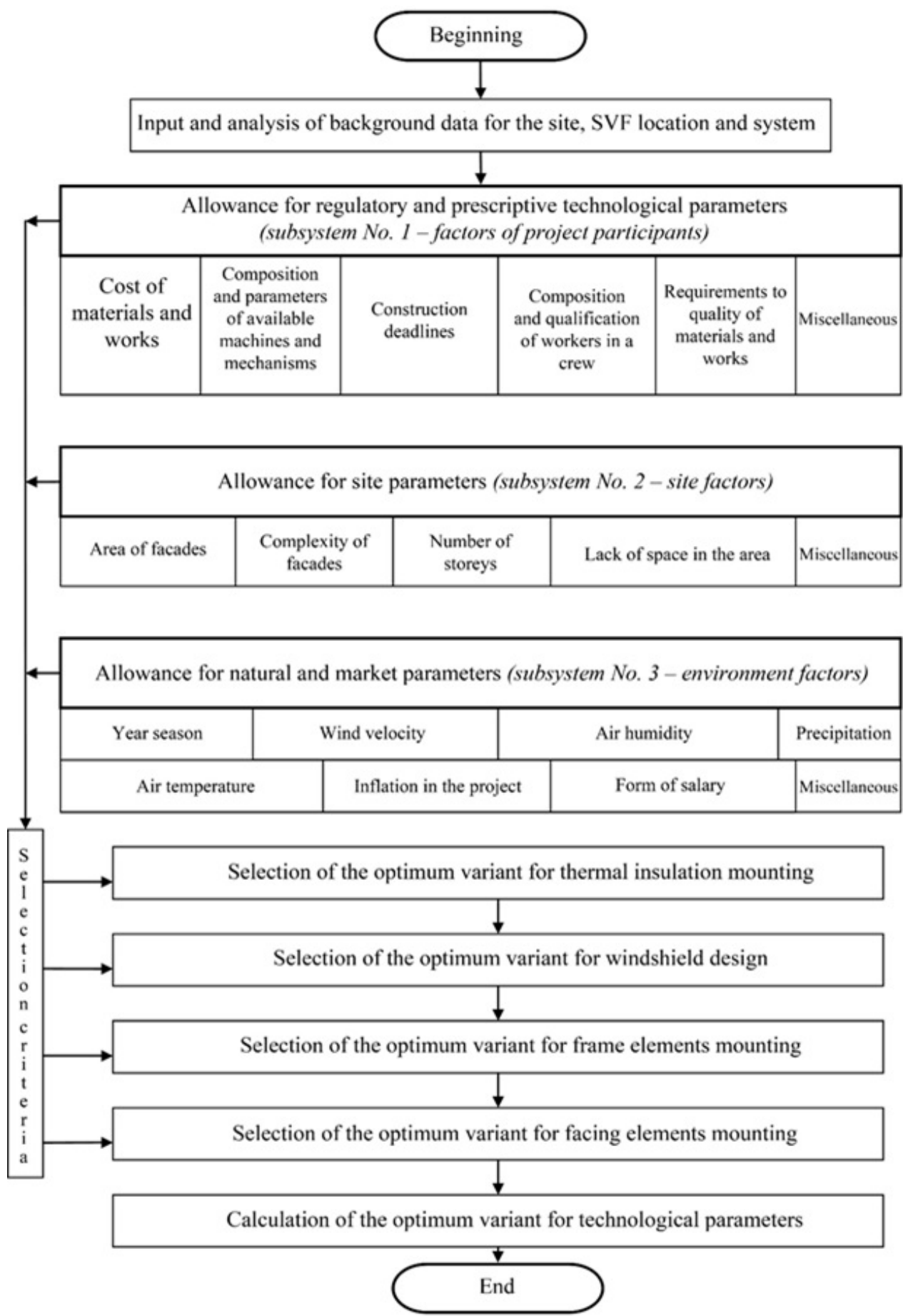

Figure 2. Algorithm for the development of the optimal technological solution for installation of SVF with the aid of the method of step-by-step multi-criteria optimization 


\section{Case history}

The authors' articles (Kazakov, 2011; Badjin et al., 2015) and those of A.Ye. Piskun, Candidate of Engineering Sciences, (Piskun, Kazakov, 2008a; Piskun, Kazakov, $2008 \mathrm{~b}$ ) as well as the materials of such papers further development in 2010-2016, formed the basis of the investigation. For that purpose modeling of optimum technological solutions was carried out for design of residential building SVF based on the minimum cost and safety criteria. Impact regularities of the key factors affecting technological solutions for SVF design were discovered and studied.

\section{Results}

Theoretical models, algorithms and recommendations for the development of rational solutions and various technologies of SVF design were elaborated (figure 1,2).
It is suggested to consider mineral wood rigid tiles made of basalt fiber as optimum thermal insulation. The following may be considered as optimum fencing: fiber cement sheets, sheets of vinyl siding, reconstituted granite tiles. The following may be considered as the frame: galvanized and stainless steel umbrella-type self-drilling bolts and bolts.

Taking into account the 4 most important consumer optimality criteria, i.e. minimum labor intensity and machine time, minimum cost, improved quality and maximum quality, 1 improved variant of rational technological solutions for installation of thermal insulation, frame and facing elements in SVF systems (figure 3) was developed.

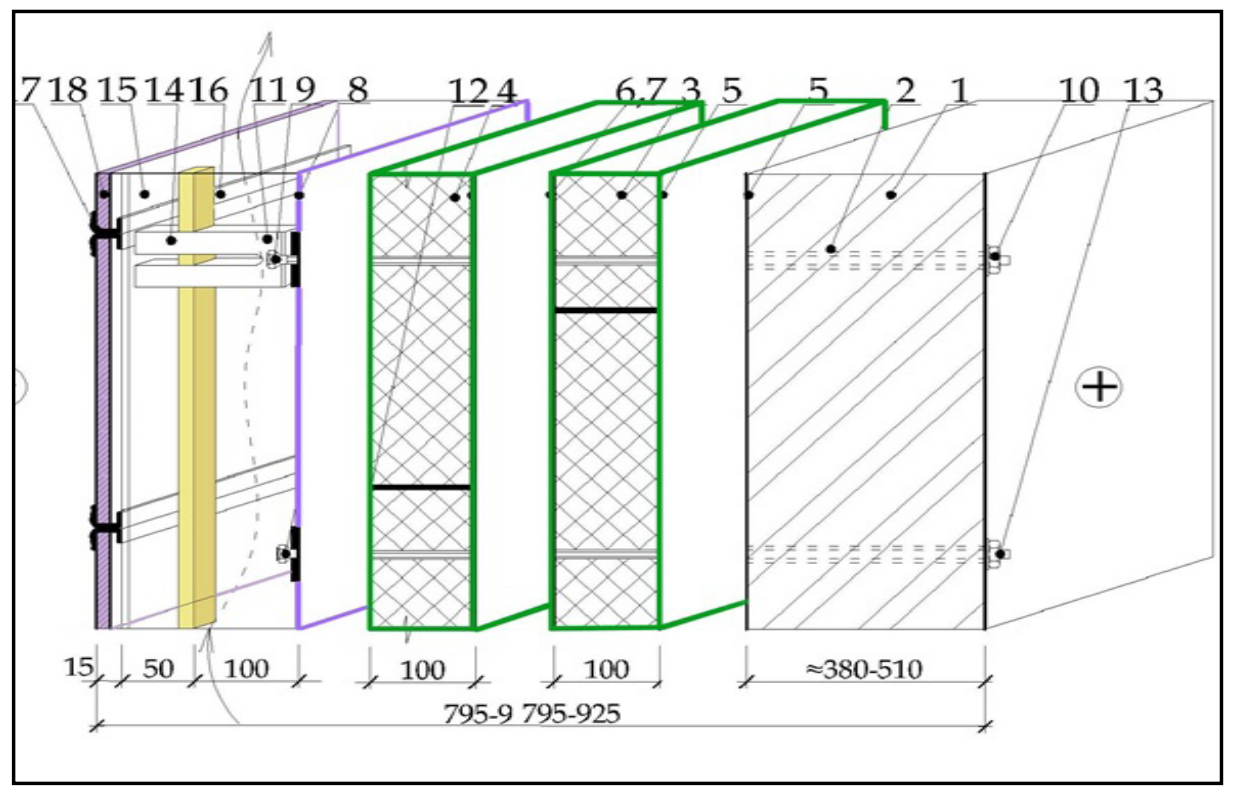

Figure 3. SVF design technology corresponding to Variant 4 in terms of optimality criterion K3 - maximum quality (recommended for use in case of unrestricted financial resources and labor force): 1 - ceramic brick laying; 2 - drilling of bolt holes; 3, 4 - installation of mineral wool plates in 2 (two) overlapping layers; 5-8 - fixing of Tyvek membrane; 9,12 - installation of passing bolts; 10,13 - nuts installation; 11,15 - mounting of horizontal and vertical guiding profiles, stainless steel; 14 - bracing; 16 - leaving a gap; 17 - mounting of shaped panel strips; 18 - mounting of granite tiles

New dependencies (important for improvement of technological effectiveness of works) of labor intensity increase on the increase of the area of mounted SVF elements, their weight and other impact factors with the criteria of optimum minimum cost, labor intensity and maximum quality were determined.

With the use of mathematical statistics methods mathematical models that approximate the discovered dependencies were calculated. With the aid of the on-site measurements method that enabled further determination of important and new dependencies of labor efficiency decrease during SVF design on the impact of the most important natural climatic factors, i.e. extremely low temperatures and wind velocity (Kazakov, 2011).

Further, technical and economic efficiency of applying rational solutions for design of residential building SVFs were studied. The analysis of variants for SVF design technologies were performed according to the results of experimental construction. The mounting cost was $2.25-3.95$ thousand rubles per 1 sq. $m$ of facade area; that is 1.3-1.6 times cheaper in comparison with existing traditional methods of non-ventilated facade design. The above results allowed to further substantiate the technological chart of suspended ventilated facade design based on the most popular and significant optimality criteria minimum labor intensity and cost of works (figure 4,5 ).

The technological chart specifies its scope, outlines the major data on work organization and production technology during mounting of ventilated facade elements, determines requirements to work quality, accident prevention, occupational safety and fire prevention measures, sets forth the need for material and technical resources, calculates labor intensity and work schedule. 


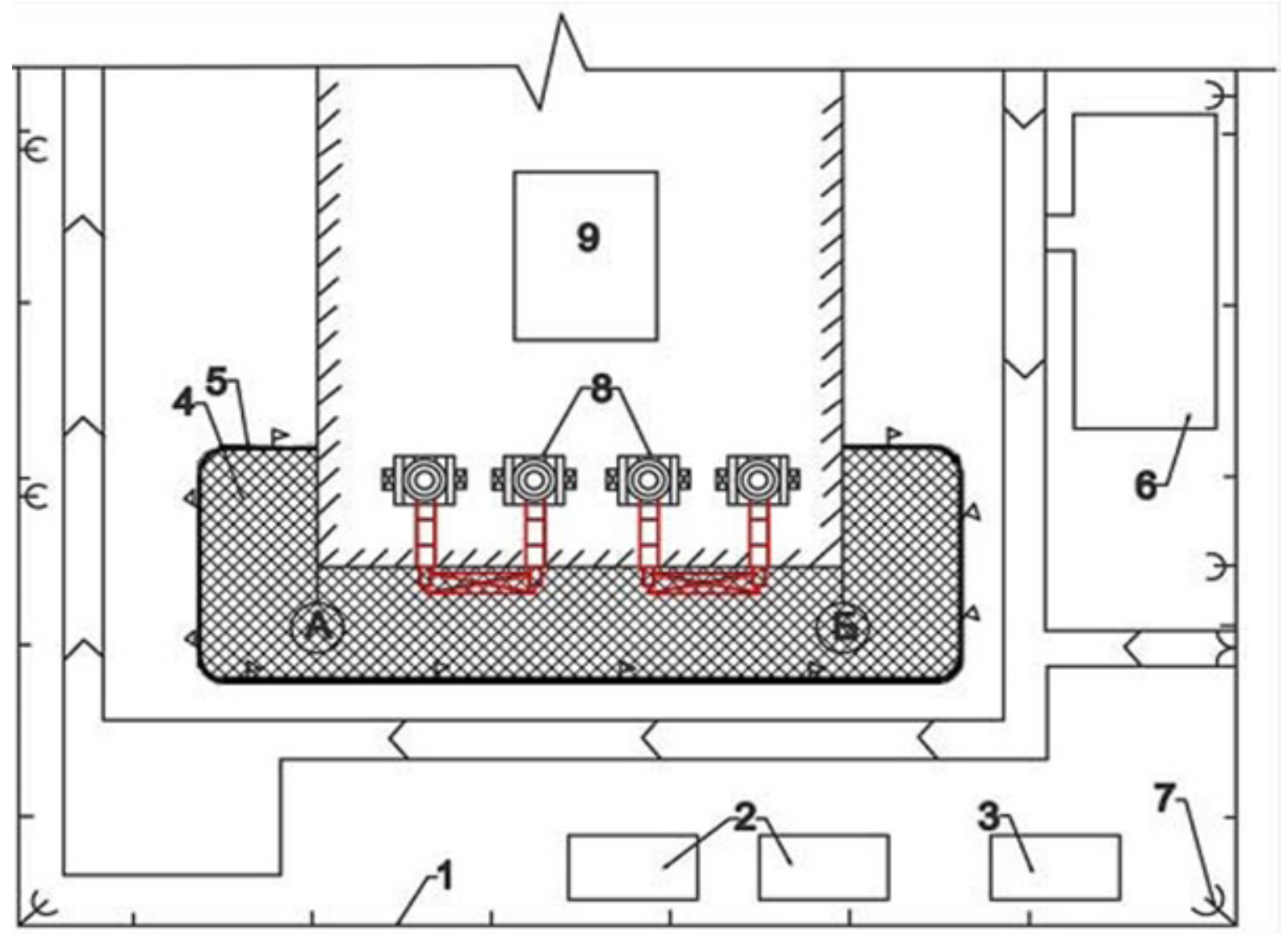

Figure 4. Diagram of the construction site organization when designing SVF rational solution with minimum costs in a multistorey building: 1 - fences of construction site; 2 - workshop, sanitary and amenity facilities for workers; 3 - materials and equipment store; 4 - work area; 5 - boarders of dangerous area for people to stay when suspended cradles are in operation; 6 - outdoor storage area for mineral wool tiles, frame elements film, facing panels; 7 - lightening tower; 8 - 2 (two) suspended cradles; 9 - residential building with SVF

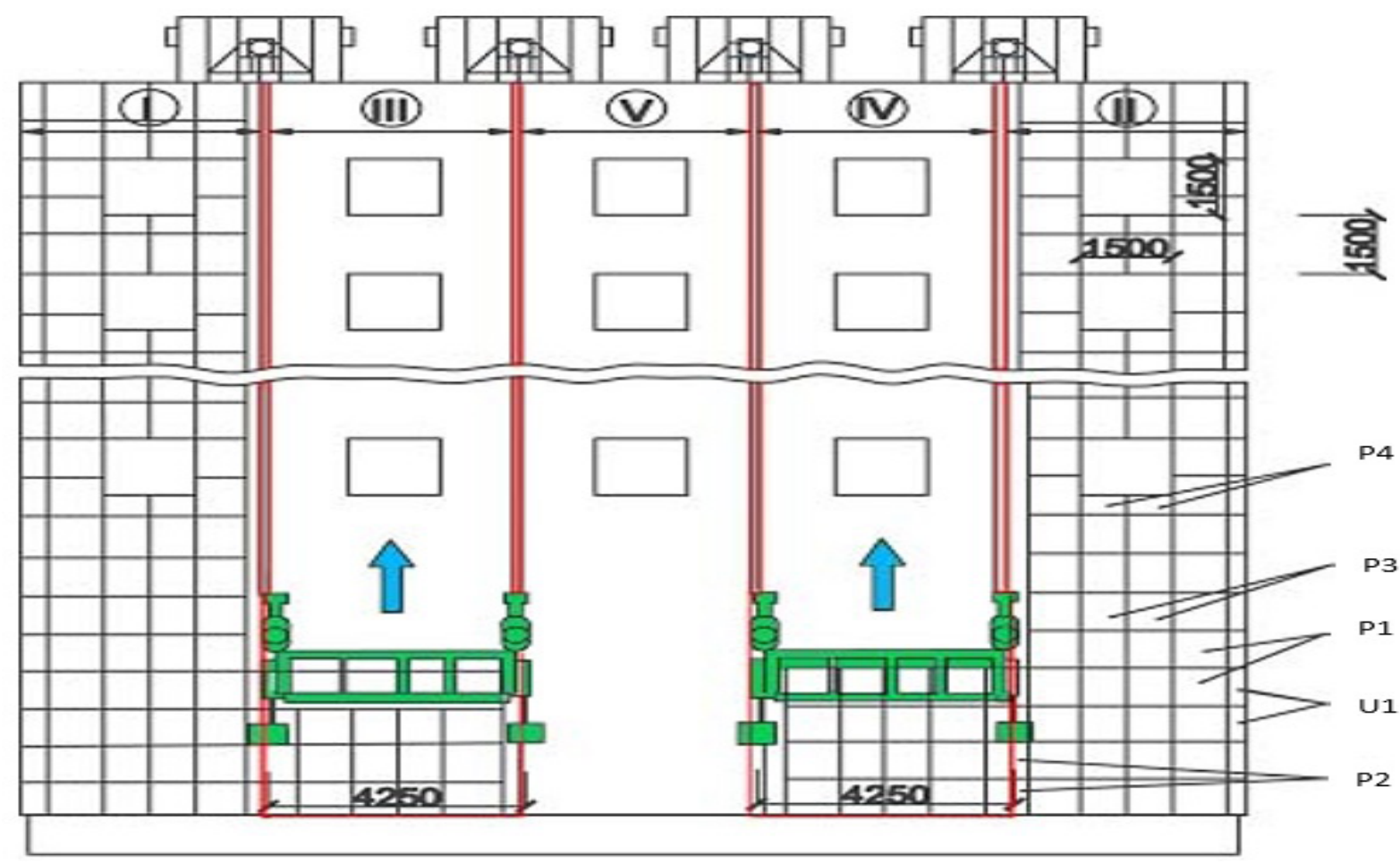

Figure 5. Diagram of facade breakdown into vertical grips when designing SVF rational solution with minimum costs in a multistorey building 
Legend to the Figure 5: - work performance direction; I, III, V - vertical grips for the 1st and 2nd mounter crews working in the first suspended cradle; II, IV - vertical grips for the 3rd and 4th mounter crews working in the second suspended cradle. Facing panels: P1 - 1000x900, P2 - 1000x700, P3 - 1000x750, P4 - 750x500, U1 $-1000 \times 200$.

Table 1. Comparative analysis of the technological parameters of 4 improved SVF design methods.

\begin{tabular}{|c|c|c|c|c|}
\hline Parameter & $\begin{array}{l}\text { Variant } 1 \text { - } \\
\text { minimum } \\
\text { cost }\end{array}$ & $\begin{array}{l}\text { Variant 2 - } \\
\text { minimum } \\
\text { labor } \\
\text { intensity }\end{array}$ & $\begin{array}{l}\text { Variant } 3 \text { - } \\
\text { enhanced } \\
\text { quality }\end{array}$ & $\begin{array}{l}\text { Variant } 4 \text { - } \\
\text { maximum } \\
\text { quality }\end{array}$ \\
\hline $\begin{array}{l}\text { Application } \\
\text { - building } \\
\text { appearance }\end{array}$ & $\begin{array}{l}\text { individual, } \\
\text { social }\end{array}$ & social & commercial & elite \\
\hline Bearing wall & $\begin{array}{l}\text { mass } \\
\text { concrete }\end{array}$ & $\begin{array}{l}\text { precast } \\
\text { reinforced } \\
\text { concrete }\end{array}$ & \begin{tabular}{|l} 
mass \\
reinforced \\
concrete
\end{tabular} & ceramic brick \\
\hline Frame & steel & $\begin{array}{l}\text { galvanized } \\
\text { steel }\end{array}$ & $\begin{array}{l}\text { stainless } \\
\text { steel }\end{array}$ & $\begin{array}{l}\text { stainless } \\
\text { steel }\end{array}$ \\
\hline Insulant & $\begin{array}{l}\text { 2-layer } \\
\text { mineral } \\
\text { wool }\end{array}$ & $\begin{array}{l}\text { 2-layer } \\
\text { mineral } \\
\text { wool }\end{array}$ & $\begin{array}{l}\text { 3-layer } \\
\text { mineral wool }\end{array}$ & $\begin{array}{l}\text { 3-layer } \\
\text { mineral wool }\end{array}$ \\
\hline $\begin{array}{l}\text { Suspended } \\
\text { facing }\end{array}$ & $\begin{array}{l}\text { vinyl } \\
\text { siding, } \\
\text { vertical } \\
\text { racks }\end{array}$ & $\begin{array}{l}\text { large fiber- } \\
\text { cement } \\
\text { facade } \\
\text { panels }\end{array}$ & $\begin{array}{l}\text { reconstituted } \\
\text { granite tiles }\end{array}$ & granite tiles \\
\hline $\begin{array}{l}\text { Frame } \\
\text { fasteners }\end{array}$ & $\begin{array}{l}\text { plastic, } \\
\text { umbrella- } \\
\text { type studs }\end{array}$ & $\begin{array}{l}\text { galvanized } \\
\text { steel, } \\
\text { rawbolts }\end{array}$ & $\begin{array}{l}\text { stainless } \\
\text { steel, } \\
\text { rawbolts }\end{array}$ & $\begin{array}{l}\text { stainless } \\
\text { steel, bolts }\end{array}$ \\
\hline Crew, people & $1-2$ & $1-2$ & $2-3$ & $2-3$ \\
\hline $\begin{array}{l}\text { Mounting } \\
\text { labor input, } \\
\text { man-shift } \\
\text { per } 1 \text { sq. m } \\
\text { of facade } \\
\text { (mean } \\
\text { calculated } \\
\text { results) }\end{array}$ & 0.62 & 0.52 & 1.31 & 1.89 \\
\hline $\begin{array}{l}\text { Cost, } \\
\text { thousand } \\
\text { rubles/sq. m }\end{array}$ & 2.17 & 3.12 & 3.1 & 3.95 \\
\hline $\begin{array}{l}\text { Insulant } \\
\text { fastener }\end{array}$ & glue & $\begin{array}{l}\text { plastic, } \\
\text { umbrella- } \\
\text { type clips }\end{array}$ & \begin{tabular}{|l} 
steel, \\
umbrella-type \\
self-drilling \\
bolts
\end{tabular} & steel, bolts \\
\hline $\begin{array}{l}\text { Technology } \\
\text { index }\end{array}$ & 0.662 & 0.655 & 0.650 & 0.645 \\
\hline
\end{tabular}

It allowed for the further comparative analysis of the technological parameters of 4 improved SVF design methods (Table 1) (Piskun, Kazakov, 2008b).

Figure 6 shows one of the discovered and studied important dependencies, i.e. lowering of SVF mounting labor intensity depending on the impact factor "increasing area of a suspended facing unit".

In conclusion, an assessment of effectiveness of the developed improved methods of HVF installation was performed under systematic consideration of the following 5 types of effectiveness at all stages of their life cycle and the type of materials (Badjin et al., 2015; Badjin et al., 2013; Sychev and Sharipova, 2015; Sychev and Kazakov, 2015).

1. Effectiveness of production of HVF elements is a characteristic of the sub-system of HVF structures manufacturing, which meets 9 criteria such as variety of types, total number of elements, material intensity, labor intensity, stress and strain, mechanization of manufacturing processes, accuracy of geometric shapes, size of elements, assembling and availability.

2. Transportation effectiveness is a characteristic of the subsystem of HVF products transportation, which meets 6 criteria such as variety of types, variety of weights, transportation costs, enlargement of prefabricated elements, loading of the rolling stock, mechanization of loading and unloading.

3. Effectiveness of installation works is a characteristic of the subsystem of HVF structures installation, which meets 10 criteria such as labor intensity, performance of wet processes, stress and strain, mechanization of processes, work rate, homogeneity of building cells, homogeneity of work zones and tiers, homogeneity of structural elements, convenience of assembling for welding, allowance for tolerances.

4. Operational effectiveness is a characteristic of the HVF in the subsystem of operation with account for the requirements of serviceability, operating costs, energy saving and automation, labor intensity and minimizing of heating costs.

5. Effectiveness of upgrading and reconstruction is a characteristic of the subsystem that takes into account the following criteria: improvement of technical performance of residential buildings, further improvement of heat protection of walls when adopting new standards, replacement of old-fashioned facing works for new types, spatial planning changes, use of new technologies, new mechanisms and equipment so that the building would meet modern requirements to safety and comfort of living.

At the same time, it is proposed that the overall effectiveness of HVF structures implies the degree of simplicity, availability, speed and ease of implementation with standard means of mechanization and a small number of semiskilled workers, a set of construction and engineering solutions for installation of facades of residential buildings, their operation, further upgrading and reconstruction meeting modern requirements to quality, safety and rates of construction processes and operations. 


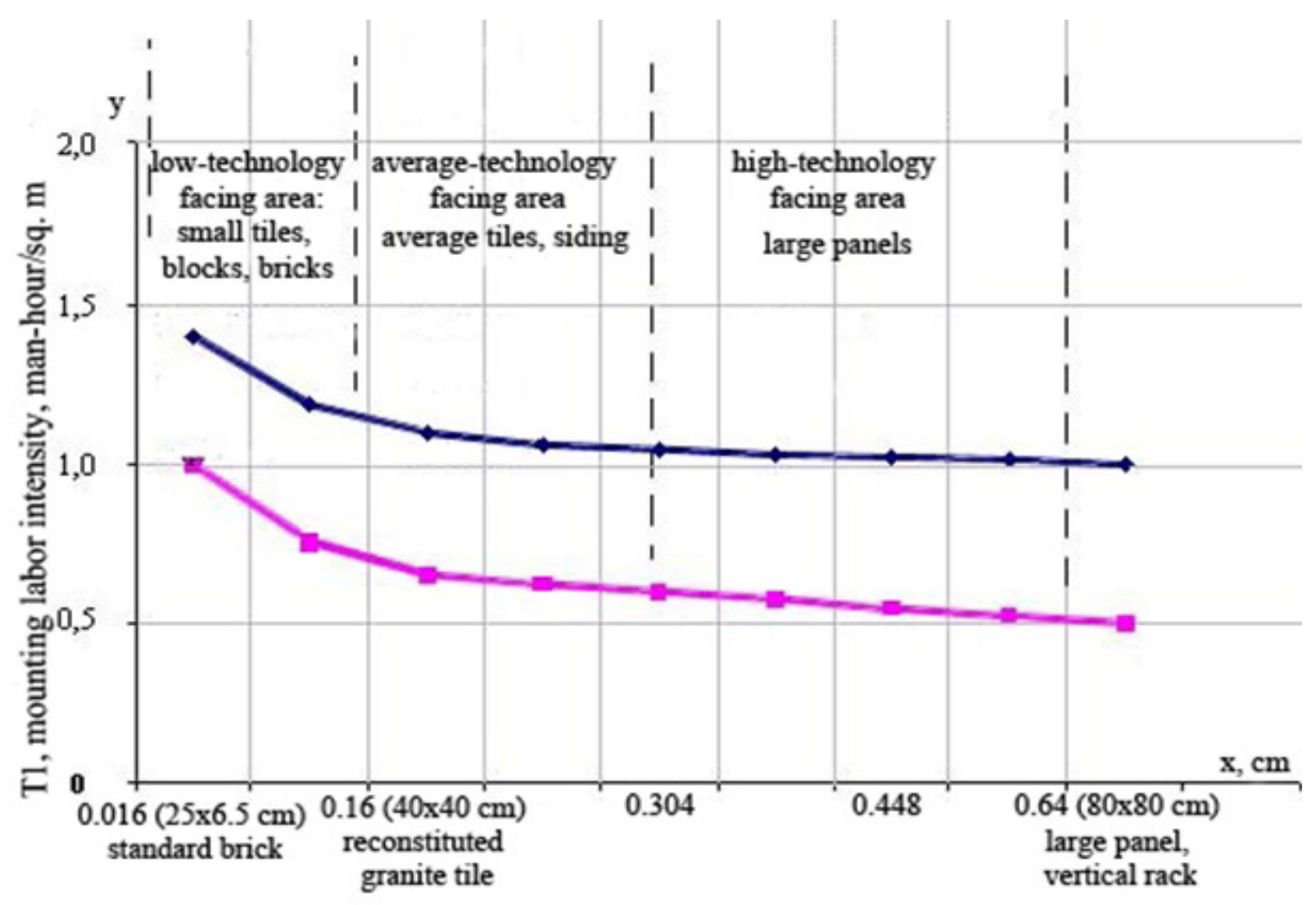

F2, area of a suspended facing unit, sq. $m$

Figure 6. Dependence of increase in SVF mounting labor intensity on impact factor - "increasing area of a suspended facing unit": upper curve - production values according to the results of measurements during the construction process, lower curve - theoretical values

The calculated values of integral criteria for effectiveness turned out to be $0.665,0.654,0.652$ and 0.650 for 4 technological solutions, corresponding to a high degree of simplicity, efficiency and industriality of construction and installation works.

\section{Conclusions}

1. It is shown that the new rational SVF solutions adequate to various types of residential buildings under construction in Russia are variants of performing of the following successive and fully-mechanized operations: 1) anchor fixing of thermal insulation (large-size mineral (glass) wool rigid tiles on a bearing wall. (2) installation of steam and wind protection membranes (polyethylene and special films). (3) mounting of the frame - vertical and horizontal profiles (galvanized or stainless steel on self-drilling bolts with anchor and fragmentary bolt fixing as per calculations to a bearing wall. (4) suspending of external facing panels with leaving an air gap as per calculations (sheets of vinyl siding, ceramic siding, fiber cement sheets, vertical racks, reconstituted granite tiles).

2. With the aid of systematic synthesis and modeling methods new theoretical models, algorithms and recommendations for developing new rational technologies of SVF design were developed. The models can be used when developing projects for construction organization and projects for performing of works in design and con38 tractor organizations. A new multifactor model of complex impact of the most significant factors (weight and sizes of insulation boards, hinged panels, elements of steel frames and fasteners, air gap width, building height, weather conditions) on optimization of technological parameters (labor intensity, machine time spending, crane equipment, cost, technological effectiveness) was substantiated.

3. With the aid of the methods of alternate technological design and multi-criteria optimization the 4 optimized variants of technological solutions for installation of thermal insulation, frame and facing elements in SVF systems were developed taking into account the 4 most important consumer optimality criteria: minimum labor intensity and machine time, minimum cost, enhanced quality, maximum quality and safety. The scientific significance of the results is that the major factors affecting optimization of technological modes of various SVF designs were identified and studied. Their use allows for the reduction of labor intensity of works to $0.55-1.88$ man-shift per $1 \mathrm{sq}$. $\mathrm{m}$ of facade area.

4. Dependencies (new and important for the reduction of labor intensity and cost as well as for enhancing simplicity and technological effectiveness of works) of increase in labor intensity on increase in area of mounted SVF elements, their weight and other impact factors were defined with optimality criteria of minimum cost, labor intensity and maximum quality. With the use of mathemati- 
cal statistics methods mathematical models that approximate the discovered dependencies were calculated. With the aid of the on-site measurement method new important dependencies of decrease in labor intensity during SVF design on the impact of the most important natural climatic factors - extremely low temperatures and wind velocity - were determined. Dependencies (new and significant for rational organizing of works for fully-mechanized mounting) of changing labor intensity and cost on the most important impact factors - changing of facade area, weight and sizes of the installed structural elements, types of units and their joints - were discovered.

5. Studies in technological effectiveness of applying rational methods of SVF design with the aid of expert assessment methods proved a quite high level of technological effectiveness of the developed solutions with integrated account for factory, transport, mounting and operational technological effectiveness as well as technological effectiveness of upgrading and reconstruction. Besides, the integral technological effectiveness criterion of the developed SVF variants was equal to 0.665 0.650 which corresponds to a high degree of simplicity, economic efficiency and industrial efficiency of performed construction and mounting works and contributes to enhancing the overall performance of the housing construction process.
6. The experience of using the developed SVF technologies together with the rational solutions by construction companies of Saint Petersburg in 2010-2016 has showed the sufficient convergence of theoretical estimate performance indicators with practical assessments of the facts of experimental construction and operation. Along with that, reasonable variants of works technology with rational SVF parameters differ from the conventional methods of SVF design by the following advantages: more cost effective consumption of available construction materials, lower labor intensity, ease in work operations performance, lower discounted value taking into account the operation stage with repairs. The competitive advantage of the construction work market is that the developed technology variants allow for the performance of works by a crew consisting of just 2-3 semiskilled (grades 3-5) workers - mounter and facing worker - virtually yearround, including at subzero temperatures as per the data (See www.expertiza-negos.ru).

7. The obtained results can also be used in development of new designs of sandwich panels, which would have prefabricated fixing of the hinged facade or its part. This would increase rates of construction and its quality, as installation of the facade at heights is very labor consuming, especially in bad weather. 


\section{Architecture and Engineering Volume 2 Issue 1}

\section{References}

Badjin, G., Sychev, S., Kazakov, Y., Judina, A. (2015). Improving Technology of Constructing Pre-Fabricated Buildings in the Conditions of Northern Regions. Applied Mechanics and Materials, 725-726, pp.100-104. DOI: 10.4028/www.scientific.net / AMM.725-726.100.

Badjin, G.M., Sychev, S.A., Pavlova, N.A. (2013). Energy-economic house: Energy-Efficient construction technologies. Transmit World, 2(1). Available at: https://transmitworld.wordpress.com/archives/ (accessed on: 02.02.2017)

Burton, S. (2014). Sustainable Retrofitting of Commercial Buildings: Cool Climates. Abingdon: Routledge.

De Gracia, A., Navarro, L., Castell, A., Ruiz-Pardo, A., Servando, A., Cabeza, L.F. (2013). Thermal analysis of a ventilated facade with PCM for cooling applications. Energy and Buildings, 65, pp. 508-515.

Godish, T. (2001). Indoor Environmental Quality. Florida: CRC Press LLC.

Hegger, J., Kulas, C., Horstmann, M. (2012). Spatial Textile Reinforcement Structures for Ventilated and Sandwich Facade Elements. Advances in Structural Engineering, 15(4), pp. 665-675. DOI: 10.1260/1369-4332.15.4.665

Kazakov, Yu.N. (2011). Kak postroit' dom: bystro i deshevo [How to erect a house: fast and cheap]. Saint Petersburg: Publishing house Piter, p.304. (in Russian)

Knaack, U., Klein, T., Bilow, M., Auer, T. (2014). Facades: Principles of Construction. 2nd and revised edition. Berlin: Birkhauser.

Piskun, A,E, Kazakov, Yu.N. (2008a). Nauchnoe obosnovanie racional'nyh tehnologicheskih reshenij primenenija NVF dlja stroitel'stva zdanij [Scientific substantiation of rational technological solutions of applying HVF for construction of buildings]. Belgorod State Technological University named after V.G. Shukhov: Publishing house of BSTU Belgorod, pp.198-204. (in Russian)

Piskun, A.E., Kazakov, Yu.N. (2008b). Racional'nye tehnologicheskie parametry ustrojstva navesnyh ventiliruemyh fasadov [Rational technological parameters of hinged ventilated facades' arrangement]. Vestnik grazhdanskikh inzhenerov [Bulletin of Civil Engineers], 4, pp. 25-29. (in Russian)

Sychev, S., Sharipova. D. (2015). Monitoring and Logistics of Erection of Prefabricated Modular Buildings. Indian Journal of Science and Technology, 8(29), pp. 1-6. DOI: 10.17485/ijst/2015/v8i29/84114.

Sychev, S.A., Kazakov, Yu.N. (2015). Domostroitel'naja sistema "Sokol" [House building System "Sokol"]. In: 1st International Conference "Sovremennye tendencii razvitija nauki i tehnologij" ["Modern aspects in development of science and technology"]. Belgorod. (in Russian)

Sychev, S.A., Kazakov, Yu.N. (2015). Vysokoskorostnaja modul'naja sistema stroitel'stva [High-speed modular system of civil engineering]. In: 3rd International Conference "Ekonomicheskie aspekty upravlenija stroitel'nym kompleksom v sovremennyh uslovijah" [Economical aspects of management of the building complex in modern conditions]. Samara, pp.183-187. (in Russian)

Tusnina, V., Emelyanov, A., Tusnina, O. (2014). A Joint of Ceramic Granite Mount by Threaded Anchor Studs in a Suspended Ventilated Facade. Applied Mechanics and Materials, 578-579, pp. 615-618. DOI: 10.4028/www.scientific.net/AMM.578-579.615

Vorob'ev V., Zapashchikova, N. (2015). Structural assessment of suspended facade systems as a tool for energy-savings and increase in energy efficiency of buildings. Naukovedenie, 7(3), pp. 1-11. DOI: 10.15862/99TVN315 